\title{
Current Pesticide Risk Assessment Protocols Do Not Adequately Address Differences between Honey Bees (Apis mellifera) and Bumble Bees (Bombus spp.)
}

\author{
Kimberly A. Stoner* \\ Department of Entomology, Connecticut Agricultural Experiment Station, New Haven, CT, USA
}

OPEN ACCESS

Edited by:

Johann G. Zaller,

University of Natural Resources and

Life Sciences, Vienna, Austria

Reviewed by:

Michalis D. Omirou,

Agricultural Research Institute, Cyprus

Leif Richardson,

The University of Vermont, USA

*Correspondence:

Kimberly A. Stoner

Kimberly.Stoner@ct.gov

Specialty section:

This article was submitted to Agroecology and Land Use Systems,

a section of the journal

Frontiers in Environmental Science

Received: 19 September 2016 Accepted: 24 November 2016 Published: 09 December 2016

Citation:

Stoner KA (2016) Current Pesticide Risk Assessment Protocols Do Not Adequately Address Differences between Honey Bees (Apis mellifera) and Bumble Bees (Bombus spp.).

Front. Environ. Sci. 4:79.

doi: 10.3389/fenvs.2016.00079
Recent research has demonstrated colony-level sublethal effects of imidacloprid on bumble bees affecting foraging and food consumption, and thus colony growth and reproduction, at lower pesticide concentrations than for honey bee colonies. However, these studies may not reflect the full effects of neonicotinoids on bumble bees because bumble bee life cycles are different from those of honey bees. Unlike honey bees, bumble bees live in colonies for only a few months each year. Assessing the sublethal effects of systemic insecticides only on the colony level is appropriate for honey bees, but for bumble bees, this approach addresses just part of their annual life cycle. Queens are solitary from the time they leave their home colonies in fall until they produce their first workers the following year. Queens forage for pollen and nectar, and are thus exposed to more risk of direct pesticide exposure than honey bee queens. Almost no research has been done on pesticide exposure to and effects on bumble bee queens. Additional research should focus on critical periods in a bumble bee queen's life which have the greatest nutritional demands, foraging requirements, and potential for exposure to pesticides, particularly the period during and after nest establishment in the spring when the queen must forage for the nutritional needs of her brood and for her own needs while she maintains an elevated body temperature in order to incubate the brood.

Keywords: queen, neonicotinoid, imidacloprid, sublethal effects, nectar consumption, pesticide exposure, incubation

\section{INTRODUCTION}

Bumble bees are major crop pollinators, particularly in temperate ecosystems. Kleijn et al. (2015) ranked 11 North American bumble bee species and seven European species among the 100 top wild bees for crop pollination value worldwide, with Bombus impatiens, Bombus terrestris/lucorum (indistinguishable in the field), and Bombus lapidarius at the top. Bumble bees pollinate springblooming crops and wildflowers under cooler and wetter weather than honey bees (Corbet et al., 1993), and pollinate flowers that require high frequency sonication (King and Buchmann, 2003). Bumble bees are keystone species in natural pollination networks because of the diversity of flowering plants they visit (Memmott et al., 2004), their ability to use flowers requiring complex behavior for pollination (Heinrich, 1979), and the long tongues of some species, allowing them to reach nectar deep in flowers not effectively pollinated by other insects (Corbet, 2000). 
The importance of bumble bees to agricultural and natural systems makes the decline in range and abundance of many bumble bee species a matter of great concern (Colla and Packer, 2008; Goulson et al., 2008; Grixti et al., 2009; Williams and Osborne, 2009; Cameron et al., 2011; Colla et al., 2012). Of the 68 species of bumble bees in Europe, 31 (45.6\%) are declining (Potts et al., 2015). Surveys of North American bumble bee species found several species in severe decline, regionally or nationally (Grixti et al., 2009; Cameron et al., 2011; Colla et al., 2012; Bartomeus et al., 2013). Similar losses have been found in parts of China (Xie et al., 2008; Williams et al., 2009), Japan (Inoue et al., 2008), and Argentina (Morales et al., 2013).

Multiple factors are implicated for these losses (Goulson et al., 2015) including: loss of long-term flowering habitat (Goulson et al., 2005; Xie et al., 2008; Grixti et al., 2009), increased infection with pathogens and parasites (Cameron et al., 2011, 2016; Szabo et al., 2012; Graystock et al., 2015), displacement of native species by imported commercial species (Inoue et al., 2008; Morales et al., 2013), and climate change (Kerr et al., 2015). The decline in bumble bee abundance and shift from early emerging to later emerging bumble bee species following spring aerial application of fenitrothion to New Brunswick forests shows that pesticide application during this sensitive period can also be a factor (Plowright et al., 1978; Plowright and Rodd, 1980).

Pesticide risk assessments require identifying pesticide concentrations causing adverse effects on species survival and reproduction, understanding the routes and magnitude of pesticide exposure and evaluating these in relation to each other at all stages of the life cycle (Sanchez-Bayo and Tennekes, 2015). Historically, pesticide risk assessments for pollinators focused on acute toxicity, using standardized methods to determine the median lethal dose $\left(\mathrm{LD}_{50}\right)$ for honey bee workers, and models to quantify honey bee contact exposure from foliar applications (Fischer and Moriarty, 2011). Reviews comparing $\mathrm{LD}_{50}$ values among bee species have shown that bumble bee workers are similar to or less sensitive than honey bee workers for most pesticides (Thompson and Hunt, 1999; Thompson, 2001; Mommaerts and Smagghe, 2011; Arena and Sgolastra, 2014; Sanchez-Bayo and Goka, 2014).

With increasing concern about losses of honey bees in North America and Europe (Vanengelsdorp and Meixner, 2010), decline of wild pollinators in Europe (Biesmeijer et al., 2006), and evidence of sublethal effects of pesticides on pollinators (Desneux et al., 2007), assessment of pesticide risks to pollinators has come under increased scrutiny. This scrutiny has particularly focused on neonicotinoid insecticides (Maxim and van der Sluijs, 2010). Although neonicotinoids have been implicated in direct mortality of honey bees (Pistorius et al., 2009; Cutler et al., 2014) and bumble bees (Xerces Society, 2014), the continuing controversy about the risk of neonicotinoid insecticides to bees rests on whether the levels to which bees are exposed cause sublethal effects on the long-term health and survival of bee populations (Blacquière et al., 2012; Godfray et al., 2014, 2015).

\section{DIFFERENCES BETWEEN HONEY BEE AND BUMBLE BEE LIFE CYCLES}

Honey bees live in eusocial colonies as superorganisms, with the queen always attended by workers (Straub et al., 2015). A honey bee queen does not forage. She leaves the protective environment of the colony only once, for her mating flight (Sammataro and Avitabile, 1998). Her exposure to pesticides is mediated by workers who collect pollen and nectar and process them into bee bread and honey. Large honey bee colonies can compensate for loss of workers from pesticide exposure, maintaining colony size and honey production, although small colonies may be more susceptible (Henry et al., 2015; Wu-Smart and Spivak, 2016).

In contrast, bumble bees live in colonies for only part of the year, and the potential for the queen to be directly exposed to pesticides, orally and by contact, is much greater than for honey bees. Unlike honey bees, which overwinter as a colony, only the mated bumble bee queen overwinters. In the typical bumble bee life cycle, after overwintering each queen must successfully establish a colony in order to reproduce, although there are also bumble bee species that are inquilines (nest parasites) on other bumble bee species, and individual queens may usurp the nests of other queens (Goulson, 2010). Many bumble bee colonies fail, and many produce only males, with generally only the largest colonies producing both males and new queens (Duchateau and Velthuis, 1988; Müller and Schmid-Hempel, 1992). This may be due to the greater resources required to produce queens. Queen larvae in Bombus terrestris require approximately $3 \mathrm{X}$ as much food as workers and $2 \mathrm{X}$ as much as males (Duchateau and Velthuis, 1988). As a result, males are generally present in excess, although in most species queens mate only once (Goulson, 2010).

The most energy-intensive period of the queen's life is after establishment of a new colony, because she not only has to forage for sufficient pollen and nectar to support herself and her larvae, but also produce enough heat to incubate the developing eggs and larvae (Heinrich, 2004). She heats this brood clump with her own body, maintaining a body temperature of $35-38^{\circ} \mathrm{C}$ day and night during the first few weeks after nest initiation to keep the brood around $30^{\circ} \mathrm{C}$ (Heinrich, 1974). Incubating Bombus vosnesenskii queens in a laboratory environment $\left(20-23^{\circ} \mathrm{C}\right)$, with a $50 \%$ sucrose solution supplied so that they did not have to forage, consumed ca. $1 \mathrm{ml}$. of sucrose solution ( $0.5 \mathrm{~g}$. of sucrose) per day, $3 \mathrm{X}$ as much as non-incubating queens (Heinrich, 1972).

Although for honey bees the gold standard for pesticide risk assessment is to evaluate effects on the long-term survival of the colony as a whole, for bumble bees, the appropriate standard is 2-fold: (1) effects on colony production of new queens and males, and (2) effects on queen success in mating, overwintering, establishing, and supporting a new colony capable of reproducing at the end of the season. A number of studies of sublethal effects of neonicotinoids have addressed foraging, growth, and reproduction of bumble bee colonies (Supplementary Table 1); very few have addressed pesticide exposure to bumble bee queens or possible effects on their fitness. 


\section{NEONICOTINOID CONCENTRATIONS WITH SUBLETHAL EFFECTS ON BUMBLE BEE COLONIES}

The specifics of 24 studies of the sublethal effects of oral exposure to neonicotinoids in bumble bee colonies are presented in Supplementary Table 1, including whether they were in the laboratory or field, the extent to which foraging was a component, the concentration and duration of exposure, and the species used. One important factor is whether workers traveled for food. This appears most dramatically in Mommaerts et al. (2010). When workers had to travel $20 \mathrm{~cm}$ to a separate box for food, exposure to imidacloprid at $10 \mathrm{ppb}$ for 14 days resulted in a significant $(60 \%)$ loss of reproduction, whereas in an otherwise identical test with the food in the nest box, there was no significant loss of reproduction at 10 or $20 \mathrm{ppb}$.

Another important distinction is between the studies with queenright colonies (queen plus workers, generally standardized by starting size) and those using micro-colonies (small artificial colonies with 3-5 workers, one of whom becomes dominant and lays eggs). Due to the haplo-diploid system of reproduction in Hymenoptera, unmated workers can produce offspring, but they are always haploid, and thus male (Goulson, 2010). Microcolonies are used only in laboratory or confined greenhouse experiments (Tasei et al., 2000; Gradish et al., 2010; Mommaerts et al., 2010); queenright colonies are used for field studies, whether the pesticide exposure happens in the field (Larson et al., 2013; Rundlöf et al., 2015), or in the laboratory followed by field foraging (Whitehorn et al., 2012; Feltham et al., 2014), or by simultaneous provision of pesticide-treated sugar water and field foraging (Gill et al., 2012; Gill and Raine, 2014; Moffat et al., 2015, 2016).

Many of the studies in Supplementary Table 1 have demonstrated adverse effects of imidacloprid on B. terrestris colonies at concentrations well below the proposed US EPA trigger levels for honey bees (No Observed Adverse Effect Concentration of $25 \mathrm{ppb}$ in nectar and the Lowest Observed Adverse Effect Concentration of $100 \mathrm{ppb}$ in pollen; United States Environmental Protection Agency, 2016). Mommaerts et al. (2010) reported significant loss of reproduction at $10 \mathrm{ppb}$ imidacloprid in micro-colonies required to travel $20 \mathrm{~cm}$ for food, and a complete loss of reproduction in queenright colonies at $10 \mathrm{ppb}$ imidacloprid when required to travel $3 \mathrm{~m}$ for food. Even without requiring the workers to travel, Laycock et al. (2012) still had a dose-dependent decrease in both sugar water and pollen consumption and a decline in brood production of microcolonies down to $1.27 \mathrm{ppb}$ imidacloprid with 14 days exposure. In a subsequent laboratory experiment, Laycock and Cresswell (2013) found a dose-dependent reduction in brood production at $0.3-10 \mathrm{ppb}$ of imidacloprid with 14 days of exposure, but the colonies substantially recovered after 14 days off dose. Bryden et al. (2013) measured birth and death rates over time in a laboratory colony at $10 \mathrm{ppb}$, and found eclosion of new workers was near zero after 21 days.

In studies requiring field foraging with $B$. terrestris and imidacloprid, Whitehorn et al. (2012) found that queenright colonies fed imidacloprid for 14 days at $6 \mathrm{ppb}$ in pollen, and
$0.7 \mathrm{ppb}$ in sugar water followed by field foraging had a modest but significant reduction in total colony weight, but a major reduction (85\%) in queen production. Feltham et al. (2014) also fed queenright colonies $6 \mathrm{ppb}$ imidacloprid in pollen and $0.7 \mathrm{ppb}$ in sugar water for 14 days and found a subsequent $31 \%$ reduction in the rate of field pollen foraging. Gill et al. (2012) and Gill and Raine (2014) used a longer period (28 days) and higher level (10 ppb in sugar water) of exposure, and similarly found effects on the efficiency of field pollen foraging and effects on worker numbers and brood. Moffat et al. (2015), providing colonies foraging freely in the field with a one-time supplement of 1500 $\mathrm{ml}$ of sugar water with $2.1 \mathrm{ppb}$ imidacloprid, found significant reductions in colony growth, viable brood and surviving bees at the end of 43 or 48 days. Repeating the experiment the next year at $2.5 \mathrm{ppb}$, there was again a significant decrease in brood cells, although changes in live bees, nest mass, and number of queens were not significant (Moffat et al., 2016).

In summary, imidacloprid consistently affects foraging and subsequently colony growth and brood production of $B$. terrestris at a level of $10 \mathrm{ppb}$ in sugar water or $6 \mathrm{ppb}$ in pollen and $0.7 \mathrm{ppb}$ in sugar water for an exposure period of 14 days. Even a sugar water supplement to natural foraging at $2.1-2.5 \mathrm{ppb}$ imidacloprid reduced brood production of colonies foraging in the field.

There are fewer studies using B. impatiens, and those found colony effects at higher imidacloprid concentrations than for B. terrestris. Scholer and Krischik (2014), testing a range of concentrations, found reduced production of males and colony weight at $14 \mathrm{ppb}$ and higher queen mortality at $16 \mathrm{ppb}$ using queenright colonies traveling $30.5 \mathrm{~cm}$ for food. Morandin and Winston (2003) found less efficient foraging behavior at $30 \mathrm{ppb}$ in mixed pollen and sugar water patties, but not at $7 \mathrm{ppb}$, and found no effect of either concentration on colony growth.

Different neonicotinoid compounds have different effects on bumble bees at the levels of neurons, feeding behavior in individual worker bees, and colonies (Kessler et al., 2015; Moffat et al., 2016). Fewer studies have been conducted with thiamethoxam and clothianidin than with imidacloprid. Moffat et al. (2016) directly compared thiamethoxam, clothianidin, and imidacloprid, each provided at $2.5 \mathrm{ppb}$ in a sugar water supplement to naturally foraging colonies in the field, and found that imidacloprid reduced the number of brood cells; thiamethoxam reduced brood cells, live bees, nest mass, and the proportion of females in B. terretstris; the only significant effect of clothianidin at that concentration was to increase the number of queens produced. By contrast Rundlöf et al. (2015), in a field study with exposure to higher concentrations of clothianidin from the nectar and pollen of seed-treated oilseed rape (mean concentration $13.9 \pm 1.8 \mathrm{ppb}$ in honey bee collected pollen, $5.4 \pm 1.4 \mathrm{ppb}$ in bumble bee nectar), found a $63 \%$ reduction in new queens produced, and also significant reductions in colony growth and production of workers and males. Field studies by Cutler and Scott-Dupree (2014) and Sterk et al. (2016) found no effect of clothianidin seed treatment on bumble bee colonies, probably because the concentrations were lowbelow $0.8 \mathrm{ppb}$ for corn pollen (Cutler and Scott-Dupree, 2014) and from $1.3 \mathrm{ppb}$ to below the level of quantification for oil seed rape pollen (Sterk et al., 2016). In a laboratory study 
with $B$. impatiens that also involved a foraging assay, Franklin et al. (2004) found no significant effects on colony health or foraging behavior at $6 \mathrm{ppb}$ and at $36 \mathrm{ppb}$. In a laboratory microcolony study, Piiroinen et al. (2016) also found no effect of clothianidin at $1 \mathrm{ppb}$, except to bees stressed in a behavioral test.

For thiamethoxam, laboratory studies differ on the levels showing negative effects, with Elston et al. (2013) finding significant delays in nest initiation, fewer eggs laid, and zero larvae produced at $10 \mathrm{ppb}$, while Laycock et al. (2014), testing a range of concentrations, found significant effects on food consumption and oviposition starting only at $39 \mathrm{ppb}$. FauserMisslin et al. (2014), in a long-term laboratory study, found that a mixture of thiamethoxam (4 ppb) and clothianidin (1.5 $\mathrm{ppb}$ ) resulted in reduced worker survival, reduced production of workers and males, and a $77 \%$ reduction in production of new queens. Stanley et al. (2016) found no effect of a $2.4 \mathrm{ppb}$ thiamethoxam sugar water supplement on colony growth, but found effects on field foraging for pollen, with longer foraging bouts producing less pollen for treated bees.

\section{LEVELS OF ORAL EXPOSURE OF BUMBLE BEE COLONIES TO NEONICOTINOIDS IN POLLEN AND NECTAR}

There are few direct measurements of pesticides in pollen or nectar collected by bumble bee colonies. David et al. (2016) provides the most comprehensive data for neonicotinoids and fungicides in pollen in rural and urban areas near Sussex (UK). They found thiamethoxam in $100 \%$ of their samples of stored bumble bee pollen from rural areas, and at surprisingly high concentrations (mean $18 \mathrm{ppb}$, median $21 \mathrm{ppb}$ ) - higher than in oilseed rape pollen, pollen from wildflowers on the borders of oilseed rape fields, and honey bee pollen from hives adjacent to the oilseed rape fields. No thiamethoxam was found in stored pollen from urban bumble bee nests, but imidacloprid was found in $1 / 3$ of the urban nests at a mean concentration of $6.5 \mathrm{ppb}$. Rundlöf et al. (2015) measured clothianidin at $5.4 \pm 1.4 \mathrm{ppb}$ in bumble bee nectar from colonies adjacent to treated oilseed rape fields with effects described above. These neonicotinoid concentrations are higher than those generally considered "field realistic" in previous reviews (Blacquière et al., 2012; Godfray et al., 2014, 2015), and are also higher than mean or median concentrations in area-wide surveys of trapped honey bee pollen (Chauzat et al., 2006; Stoner and Eitzer, 2013) or stored honey bee bread (Lawrence et al., 2016).

\section{Knowledge Gaps}

Pesticide risk assessment requires evaluating toxicity (acute, chronic, and sublethal) and exposure (contact and oral) and then evaluating the relationship between toxicity and exposure (Sanchez-Bayo and Tennekes, 2015). Throughout this complex process, it is crucial to keep the protection goals in mind. A workshop of government, academic, and industry representatives identified the protection goal "to maintain pollinator services and the biodiversity and abundance of bumble bees in a specific area" (Cabrera et al., 2015). These are knowledge gaps I see in achieving this protection goal throughout the bumble bee life cycle:

\section{Effects of Pesticide Exposure of Colonies on Queen Production}

The appropriate metric for colony fitness is the production of queens and, to a lesser extent, males, because only mated queens overwinter and establish new colonies. Few of the studies in Supplementary Table 1 reported on queen production (Whitehorn et al., 2012; Larson et al., 2013; Fauser-Misslin et al., 2014; Scholer and Krischik, 2014; Moffat et al., 2016).

TABLE 1 | Critical periods for nutrition of bumble bee queens.

\begin{tabular}{|c|c|c|c|c|c|}
\hline Stage & Typical timing & Typical duration & Food consumption & $\begin{array}{l}\text { Species } \\
\text { studied }\end{array}$ & References \\
\hline Larval development of queens & Late summer & 9-10 days & $\begin{array}{l}\text { Total over larval development: Pollen }= \\
0.11 \mathrm{~g} \text { (range } 0.75-1.35 \text { ) in regurgitated } \\
\text { mix with nectar and proteins }\end{array}$ & B. ruderatus & Pomeroy, 1979 \\
\hline $\begin{array}{l}\text { Initial feeding by new adult } \\
\text { queens to prepare for hibernation }\end{array}$ & Late summer or Fall & 3-6 days & $\begin{array}{l}\text { Total over } 6 \text { days: Pollen }=0.28 \mathrm{~g} \text { (range } \\
0.22-0.36) . \text { Nectar (converted to } 50 \% \\
\text { sugar) }=1.41 \mathrm{~g} \text { (range 0.98-2.06) }\end{array}$ & $\begin{array}{l}\text { B. terrestris, } \\
\text { B. ruderatus }\end{array}$ & $\begin{array}{l}\text { Pomeroy, 1979; Přidal } \\
\text { and Hofbauer, } 1996 \\
\text { (pollen only) }\end{array}$ \\
\hline Hibernation & Winter to Early Spring & Variable with climate & $\begin{array}{l}\text { Metabolizing fat and glycogen reserves: } \\
\text { e.g., B. lapidarius consumes } 90.6 \mathrm{mg} \text { fat } \\
\text { ( } 94 \% \text { of fat reserves and } 191 \mathrm{mg} \text { dry wt. } \\
\text { (75\%). Consumption of honey in honey } \\
\text { stomach ( } 20 \% \text { water) Mean }=141 \mathrm{mg} \\
\text { (75\% of total in stomach) }\end{array}$ & $\begin{array}{l}\text { Mixed species } \\
\text { hibernating in } \\
\text { Southern } \\
\text { England }\end{array}$ & Alford, 1969 \\
\hline $\begin{array}{l}\text { Initial foraging after hibernation to } \\
\text { stimulate ovaries }\end{array}$ & Early Spring & Ca. 18 days & $\begin{array}{l}\text { Weight gain of } 109 \mathrm{mg} \text { over } 18 \text { days, } \\
\text { consuming both pollen and nectar }\end{array}$ & B. lucorum & Cumber, 1949 \\
\hline Non-incubating queens & Early Spring & 3-21 days & $\begin{array}{l}0.30-0.38 \mathrm{ml} \text { of } 50 \% \text { sucrose per day } \\
\text { (laboratory) }\end{array}$ & B. vosnesenskii & Heinrich, 1972 \\
\hline Incubation of brood nest & Late Spring & Ca. 30 days & $\begin{array}{l}0.90-1.14 \mathrm{ml} \text { of } 50 \% \text { sucrose per day } \\
\text { (laboratory) }\end{array}$ & B. vosnesenskii & Heinrich, 1972 \\
\hline
\end{tabular}




\section{Food Consumption of Bumble Bee Queens during Critical Life Stages}

Bumble bee queens have several critical periods of foraging between their emergence as adults in the fall and when the first cohort of workers takes over foraging the following spring (Table 1). As noted above, spring nest establishment and incubation make the greatest foraging demands on queens. In addition to the energy expenditure for nest incubation (Heinrich, 1972), queens must also expend significant energy in nectar foraging, requiring major investments in warm-up for flight (depending on ambient temperature) and for flight itself. Foraging is required daily, since the queen's energy storage in her honey pot is only sufficient for a few hours of incubation (Heinrich, 2004). Spring foraging is also highly localized to minimize the energy expense of extended flight and minimize time away from the nest (Heinrich, 2004).

The estimates of food consumption for each critical stage in Table 1 were gleaned from literature on several different species, but at least laboratory estimates for each critical period for B. terrestris and B. impatiens, which are commercially available and crucial crop pollinators, should be measured. Food consumption at each stage is important to assess acute toxicity by relating pesticide concentration in pollen and nectar to an oral dose per queen bee, which can then be related to the $\mathrm{LD}_{50}$ (Stoner and Eitzer, 2013), although both the oral dose and the $\mathrm{LD}_{50}$ would need to be standardized for differences in weight between queens and workers and for variation among queens (Thompson and Hunt, 1999).

\section{Major Sources of Nectar and Pollen for Bumble Bee Queens during Critical Life Stages}

Detailed studies of pollen and nectar sources of spring bumble bee queens have been made in west Scotland (Brian, 1957), Wisconsin (Macior, 1968), and sub-Alpine environments near Mount Hood in Oregon (Macior, 1994), and could be extracted from season-long surveys of bumble bee visits to flowers (e.g., Fussell and Corbet, 1992) and from analysis of pollen on queens from museum collections (Scheper et al., 2014). Bumble bee queens have been frequently noted as pollinators of springblooming fruit trees and bushes (e.g., lowbush blueberry: Stubbs et al., 1992; Javorek et al., 2002; apple: Macior, 1968; Adamson et al., 2012; Russo et al., 2015), and thus use of pesticides on these crops and on spring-blooming ornamental shrubs and trees attractive to bumble bee queens, such as rhododendron, lilac and honeysuckle (Evans et al., 2007), may pose a particular hazard in this critical stage of the bumble bee life cycle.

\section{Potential Effects of Pesticide Exposure on Bumble Bee Queens}

There is no data on whether pesticide exposure has sublethal effects on the solitary stages of bumble bee queens. Bumble bee queens have major physiological differences from workers because they build up fat reserves for overwintering, consume those resources during hibernation, and then switch over to ovary development, nest establishment, wax production, and incubation (Votavová et al., 2015). A recent paper (Chaimanee et al., 2016) reported loss of viability of sperm stored in the spermatheca of honey bee queens exposed to $20 \mathrm{ppb}$ of imidacloprid for 7 days. Bumble bee queens mate before overwintering and store sperm for months before beginning oviposition, so they could be similarly affected.

\section{CONCLUSION}

Although, eusocial bee colonies are buffered from the effects of pesticides in relation to their size (Henry et al., 2015; Straub et al., 2015; Wu-Smart and Spivak, 2016), and the solitary queen phase of the bumble bee life cycle and early nest establishment are likely the periods of greatest sensitivity to pesticides (Thompson, 2001; Cabrera et al., 2015), current recommendations for additional risk assessment protocols for bumble bees focus exclusively on colonies (Cabrera et al., 2015). These recommendations may become policy not only for neonicotinoids, but also for other pesticides as pollinator health rises in importance to regulatory agencies. There is danger in limiting pesticide risk assessment to what is likely the least sensitive stage of the bumble bee life cycle.

Future pesticide risk assessments should be directed by a model based on expert knowledge of bumble bee ecology throughout the life cycle identifying the most critical points for targeted research (Henry et al., 2016). In the meantime, evaluation of pesticide concentrations that interfere with nest establishment, nectar foraging, and brood incubation, and comparison of those concentrations to probable exposures on pesticide-treated spring blooming crops would be apparent priorities for research.

\section{AUTHOR CONTRIBUTIONS}

The author confirms being the sole contributor of this work and approved it for publication.

\section{FUNDING}

Funding for related research came from the US Department of Agriculture National Institute of Food and Agriculture grant NIFA 2011-51181-30673, and from the Connecticut Department of Energy and Environmental Protection.

\section{ACKNOWLEDGMENTS}

Thanks to Tracy Zarrillo for invaluable assistance in compiling and summarizing the material in Supplementary Table 1 and to Morgan Lowry for assistance in editing. Thanks also to Bernd Heinrich for the correspondence about nectar consumption during nest incubation that initiated this project, and to the reviewers for helpful comments.

\section{SUPPLEMENTARY MATERIAL}

The Supplementary Material for this article can be found online at: http://journal.frontiersin.org/article/10.3389/fenvs. 2016.00079/full\#supplementary-material 


\section{REFERENCES}

Adamson, N. L., Roulston, T. H., Fell, R. D., and Mullins, D. E. (2012). From April to August-Wild bees pollinating crops through the growing season in Virginia, U.S.A. Environ. Entomol. 41, 813-821. doi: 10.1603/EN12073

Alford, D. V. (1969). A study of the hibernation of bumblebees (Hymenoptera: Bombidae) in southern England. J. Anim. Ecol. 38, 149-170. doi: 10.2307/2743

Arena, M., and Sgolastra, F. (2014). A meta-analysis comparing the sensitivity of bees to pesticides. Ecotoxicology 23, 324-334. doi: 10.1007/s10646-014-1190-1

Bartomeus, I., Ascher, J. S., Gibbs, J., Danforth, B. N., Wagner, D. L., Hedtke, S. M., et al. (2013). Historical changes in northeastern US bee pollinators related to shared ecological traits. Proc. Nat. Acad. Sci. U.S.A. 110, 4656-4660. doi: $10.1073 /$ pnas. 1218503110

Biesmeijer, J. C., Roberts, S. P. M., Reemer, M., Ohlemüller, R., Edwards, M., Peeters, T., et al. (2006). Parallel declines in pollinators and insectpollinated plants in Britain and the Netherlands. Science 313, 351-354. doi: $10.1126 /$ science. 1127863

Blacquière, T., Smagghe, G., Van Gestel, C. A., and Mommaerts, V. (2012). Neonicotinoids in bees: a review on concentrations, side-effects and risk assessment. Ecotoxicology 21, 973-992. doi: 10.1007/s10646-012-0863-x

Brian, A. D. (1957). Differences in the flowers visited by four species of bumblebees and their causes. J. Anim. Ecol. 1, 71-98. doi: 10.2307/1782

Bryden, J., Gill, R. J., Mitton, R. A., Raine, N. E., and Jansen, V. A. (2013). Chronic sublethal stress causes bee colony failure. Ecol. Lett. 16, 1463-1469. doi: 10.1111/ele. 12188

Cabrera, A. R., Almanza, M. T., Cutler, G. C., Fischer, D. L., Hinarejos, S., Lewis, G., et al. (2015). Initial recommendations for higher-tier risk assessment protocols for bumble bees, Bombus spp. (Hymenoptera: Apidae). Integr. Environ. Assess. Manage. 12, 222-229. doi: 10.1002/ieam.1675

Cameron, S. A., Lim, H. C., Lozier, J. D., Duennes, M. A., and Thorp, R. (2016). Test of the invasive pathogen hypothesis of bumble bee decline in North America. Proc. Nat. Acad. Sci. U.S.A. 113, 4386-4391. doi: 10.1073/pnas.1525266113

Cameron, S. A., Lozier, J. D., Strange, J. P., Koch, J. B., Cordes, N., Solter, L. F., et al. (2011). Patterns of widespread decline in North American bumble bees. Proc. Nat. Acad. Sci. U.S.A. 108, 662-667. doi: 10.1073/pnas.1014743108

Chaimanee, V., Evans, J. D., Chen, Y., Jackson, C., and Pettis, J. S. (2016). Sperm viability and gene expression in honey bee queens (Apis mellifera) following exposure to the neonicotinoid insecticide Imidacloprid and the organophosphate Acaricide Coumaphos. J. Insect Physiol. 89, 1-8. doi: 10.1016/j.jinsphys.2016.03.004

Chauzat, M. P., Faucon, J. P., Martel, A. C., Lachaize, J., Cougoule, N., and Aubert, M. (2006). A survey of pesticide residues in pollen loads collected by honey bees in France. J. Econ. Entomol. 99, 253-262. doi: 10.1093/jee/99.2.253

Colla, S. R., Gadallah, F., Richardson, L., Wagner, D., and Gall, L. (2012). Assessing declines of North American bumble bees (Bombus spp.) using museum specimens. Biodivers. Conserv. 21, 3585-3595. doi: 10.1007/s10531-0120383-2

Colla, S. R., and Packer, L. (2008). Evidence for decline in eastern North American bumblebees (Hymenoptera: Apidae), with special focus on Bombus affinis Cresson. Biodivers. Conserv. 17, 1379-1391. doi: 10.1007/s10531-008-9340-5

Corbet, S. A. (2000). Conserving compartments in pollination webs. Conserv. Biol. 14, 1229-1231. doi: 10.1046/j.1523-1739.2000.00014.x

Corbet, S. A., Fussell, M., Ake, R., Fraser, A., Gunson, C., Savage, A., et al. (1993). Temperature and the pollinating activity of social bees. Ecol. Entomol. 18, 17-30. doi: 10.1111/j.1365-2311.1993.tb01075.x

Cumber, R. A. (1949). The biology of humble bees, with special reference to the production of the worker caste. Trans. R. Entomol. Soc. Lond. 100, 1-45. doi: 10.1111/j.1365-2311.1949.tb01420.x

Cutler, G. C., and Scott-Dupree, C. D. (2014). A field study examining the effects of exposure to neonicotinoid seed-treated corn on commercial bumble bee colonies. Ecotoxicology 23,1755-1763. doi: 10.1007/s10646-014-1340-5

Cutler, G. C., Scott-Dupree, C. D., and Drexler, D. M. (2014). Honey bees, neonicotinoids, and bee incident reports: the Canadian situation. Pest Manag. Sci. 70, 779-783. doi: 10.1002/ps.3613

David, A., Botías, C., Abdul-Sada, A., Nicholls, E., Rotheray, E. L., Hill, E. M., et al. (2016). Widespread contamination of wildflower and bee-collected pollen with complex mixtures of neonicotinoids and fungicides commonly applied to crops. Environ. Int. 88, 169-178. doi: 10.1016/j.envint.2015.12.011
Desneux, N., Decourtye, A., and Delpuech, J. M. (2007). The sublethal effects of pesticides on beneficial arthropods. Annu. Rev. Entomol. 52, 81-106. doi: 10.1146/annurev.ento.52.110405.091440

Duchateau, M. J., and Velthuis, H. H. W. (1988). Development and reproductive strategies in Bombus terrestris colonies. Behaviour 107, 186-207. doi: 10.1163/156853988X00340

Elston, C., Thompson, H. M., and Walters, K. F. (2013). Sub-lethal effects of thiamethoxam, a neonicotinoid pesticide, and propiconazole, a DMI fungicide, on colony initiation in bumblebee (Bombus terrestris) microcolonies. Apidologie 44, 563-574. doi: 10.1007/s13592-013-0206-9

Evans, E., Burns, I., and Spivak, M. (2007). Befriending Bumble Bees: A Practical Guide to Raising Local Bumble Bees. Available online at: http://conservancy.umn.edu/handle/11299/51331

Fauser-Misslin, A., Sadd, B. M., Neumann, P., and Sandrock, C. (2014). Influence of combined pesticide and parasite exposure on bumblebee colony traits in the laboratory. J. Appl. Ecol. 51, 450-459. doi: 10.1111/1365-2664.12188

Feltham, H., Park, K., and Goulson, D. (2014). Field realistic doses of pesticide imidacloprid reduce bumblebee pollen foraging efficiency. Ecotoxicology 23, 317-323. doi: 10.1007/s10646-014-1189-7

Fischer, D., and Moriarty, T. (2011). Pesticide Risk Assessment for Pollinators: Summary of a SETAC Pellston Workshop. Pensacola, F.L: Society of Environmental Toxicology and Chemistry (SETAC). Available online at: https://c.ymcdn.com/sites/www.setac.org/resource/resmgr/publications_and_ resources/executivesummarypollinators.pdf

Franklin, M. T., Winston, M. L., and Morandin, L. A. (2004). Effects of clothianidin on Bombus impatiens (Hymenoptera: Apidae) colony health and foraging ability. J. Econ. Entomol. 97, 369-373. doi: 10.1603/0022-0493-97.2.369

Fussell, M., and Corbet, S. A. (1992). Flower usage by bumble-bees: a basis for forage plant management. J. Appl. Ecol. 29, 451-465. doi: 10.2307/2 404513

Gill, R. J., and Raine, N. E. (2014). Chronic impairment of bumblebee natural foraging behaviour induced by sublethal pesticide exposure. Funct. Ecol. 28, 1459-1471. doi: 10.1111/1365-2435.12292

Gill, R. J., Ramos-Rodriguez, O., and Raine, N. E. (2012). Combined pesticide exposure severely affects individual-and colony-level traits in bees. Nature 491, 105-108. doi: 10.1038/nature11585

Godfray, H. C. J., Blacquière, T., Field, L. M., Hails, R. S., Petrokofsky, G., Potts, S. G., et al. (2014). A restatement of the natural science evidence base concerning neonicotinoid insecticides and insect pollinators. Proc. Biol. Sci. 281:20140558. doi: $10.1098 / \mathrm{rspb} .2014 .0558$

Godfray, H. C., Blacquiere, T., Field, L. M., Hails, R. S., Potts, S. G., Raine, N. E., et al. (2015). A restatement of recent advances in the natural science evidence base concerning neonicotinoid insecticides and insect pollinators. Proc. Biol. Sci. 282:20151821. doi: 10.1098/rspb.2015.1821

Goulson, D. (2010). Bumblebees: Behaviour, Ecology, and Conservation, 2nd Edn. Oxford: Oxford University Press.

Goulson, D., Hanley, M. E., Darvill, B., Ellis, J. S., and Knight, M. E. (2005). Causes of rarity in bumblebees. Biol. Conserv. 122, 1-8. doi: 10.1016/j.biocon.2004.06.017

Goulson, D., Lye, G. C., and Darvill, B. (2008). Decline and conservation of bumble bees. Annu Rev. Entomol. 53, 191-208. doi: 10.1146/annurev.ento.53.103106.093454

Goulson, D., Nicholls, E., Botías, C., and Rotheray, E. L. (2015). Bee declines driven by combined stress from parasites, pesticides, and lack of flowers. Science 347:1255957. doi: 10.1126/science. 1255957

Gradish, A. E., Scott-Dupree, C. D., Shipp, L., Harris, C. R., and Ferguson, G. (2010). Effect of reduced risk pesticides for use in greenhouse vegetable production on Bombus impatiens (Hymenoptera: Apidae). Pest Manag. Sci. 66, 142-146. doi: 10.1002/ps.1846

Graystock, P., Blane, E. J., McFrederick, Q. S., Goulson, D., and Hughes, W. O. (2015). Do managed bees drive parasite spread and emergence in wild bees? Int. J. Parasitol. 5, 64-75. doi: 10.1016/j.ijppaw.2015.10.001

Grixti, J. C., Wong, L. T., Cameron, S. A., and Favret, C. (2009). Decline of bumble bees (Bombus) in the North American Midwest. Biol. Conserv. 142, 75-84. doi: 10.1016/j.biocon.2008.09.027

Heinrich, B. (1972). Physiology of brood incubation in the bumblebee queen, Bombus vosnesenskii. Nature 239, 223-225. doi: 10.1038/239 $223 \mathrm{a} 0$ 
Heinrich, B. (1974). Thermoregulation in bumblebees. I. Brood incubation by Bombus vosnesenskii queens. J. Comp. Physiol. 88, 129-140. doi: 10.1007/BF00695404

Heinrich, B. (1979). "Majoring" and "minoring" by foraging bumblebees, Bombus vagans: an experimental analysis. Ecology 60, 245-255. doi: 10.2307/1937652

Heinrich, B. (2004). Bumblebee Economic, 2nd Edn. Cambridge, MA: Harvard University Press.

Henry, M., Becher, M. A., Osborne, J. L., Kennedy, P. J., Aupinel, P., Bretagnolle, V., et al. (2016). Predictive systems models can help elucidate bee declines driven by multiple combined stressors. Apidologie. doi: 10.1007/s13592-016-0476-0. [Epub ahead of print].

Henry, M., Cerrutti, N., Aupinel, P., Decourtye, A., Gayrard, M., Odoux, J. F., et al. (2015). Reconciling laboratory and field assessments of neonicotinoid toxicity to honeybees. Proc. R. Soc. B 282:20152110. doi: 10.1098/rspb.2015.2110

Inoue, M. N., Yokoyama, J., and Washitani, I. (2008). Displacement of Japanese native bumblebees by the recently introduced Bombus terrestris (L.)(Hymenoptera: Apidae). J. Insect Conserv. 12, 135-146. doi: 10.1007/s10841-007-9071-z

Javorek, S. K., Mackenzie, K. E., and Vander Kloet, S. P. (2002). Comparative pollination effectiveness among bees (Hymenoptera: Apoidea) on lowbush blueberry (Ericaceae: Vaccinium angustifolium). Ann. Entomol. Soc. Am. 95, 345-351. doi: 10.1603/0013-8746(2002)095[0345:CPEABH]2.0.CO;2

Kerr, J. T., Pindar, A., Galpern, P., Packer, L., Potts, S. G., Roberts, S. M., et al. (2015). Climate change impacts on bumblebees converge across continents. Science 349, 177-180. doi: 10.1126/science.aaa7031

Kessler, S. C., Tiedeken, E. J., Simcock, K. L., Derveau, S., Mitchell, J., Softley, S., et al. (2015). Bees prefer foods containing neonicotinoid pesticides. Nature 521, 74-76. doi: 10.1038/nature 14414

King, M. J., and S. L., Buchmann (2003). Floral sonication by bees: Mesosomal vibration by Bombus and Xylocopa, but not Apis (Hymenoptera: Apidae), ejects pollen from poricidal anthers. J. Kansas Entomol. Soc. 76, 295-305. Available online at: http://www.jstor.org/stable/i25086090

Kleijn, D., Winfree, R., Bartomeus, I., Carvalheiro, L. G., Henry, M., Isaacs, R., et al. (2015). Delivery of crop pollination services is an insufficient argument for wild pollinator conservation. Nat. Commun. 6, 7414. doi: 10.1038/ ncomms 8414

Larson, J. L., Redmond, C. T. and Potter, D. A. (2013). Assessing insecticide hazard to bumble bees foraging on flowering weeds in treated lawns. PLoS ONE 8:e66375. doi: 10.1371/journal.pone.0066375

Lawrence, T. J., Culbert, E. M., Felsot, A. S., Hebert, V. R., and Sheppard, W. S. (2016). Survey and risk assessment of Apis mellifera (Hymenoptera: Apidae) exposure to neonicotinoid pesticides in urban, rural, and agricultural settings. J. Econ. Entomol. 109, 520-528. doi: 10.1093/jee/tov397

Laycock, I., Cotterell, K. C., O'Shea-Wheller, T. A., and Cresswell, J. E. (2014). Effects of the neonicotinoid pesticide thiamethoxam at field-realistic levels on microcolonies of Bombus terrestris worker bumble bees. Ecotoxicol. Environ. Saf. 100, 153-158. doi: 10.1016/j.ecoenv.2013.10.027

Laycock, I., and Cresswell, J. E. (2013). Repression and recuperation of brood production in Bombus terrestris bumble bees exposed to a pulse of the neonicotinoid pesticide imidacloprid. PLOS ONE 8:e79872. doi: 10.1371/journal.pone.0079872

Laycock, I., Lenthall, K. M., Barratt, A. T., and Cresswell, J. E. (2012). Effects of imidacloprid, a neonicotinoid pesticide, on reproduction in worker bumble bees (Bombus terrestris). Ecotoxicology 21, 1937-1945. doi: 10.1007/s10646-012-0927-y

Macior, L. W. (1968). Bombus (Hymenoptera, Apidae) queen foraging in relation to vernal pollination in Wisconsin. Ecology 49, 20-25. doi: 10.2307/1933556

Macior, L. W. (1994). Pollen-foraging dynamics of subalpine bumblebees (Bombus Latr.). Plant Species Biol. 9, 99-106. doi: 10.1111/j.1442-1984.1994. tb00089.x

Maxim, L., and van der Sluijs, J. P. (2010). Expert explanations of honeybee losses in areas of extensive agriculture in France: Gaucho ${ }^{\circledR}$ compared with other supposed causal factors. Environ. Res. Lett. 5:014006. doi: 10.1088/1748-9326/5/1/014006

Memmott, J., Waser, N. M., and Price, M. V. (2004). Tolerance of pollination networks to species extinctions. Proc. R. Soc. B. 271, 2605-2611. doi: 10.1098/rspb.2004.2909
Moffat, C., Buckland, S. T., Samson, A. J., McArthur, R., Pino, V. C., Bollan, K. A., et al. (2016). Neonicotinoids target distinct nicotinic acetylcholine receptors and neurons, leading to differential risks to bumblebees. Sci. Rep. 6:24764. doi: $10.1038 /$ srep24764

Moffat, C., Pacheco, J. G., Sharp, S., Samson, A. J., Bollan, K. A., Huang, J., et al. (2015). Chronic exposure to neonicotinoids increases neuronal vulnerability to mitochondrial dysfunction in the bumblebee (Bombus terrestris). FASEB J. 29, 2112-2119. doi: 10.1096/fj.14-267179

Mommaerts, V., Reynders, S., Boulet, J., Besard, L., Sterk, G., and Smagghe, G. (2010). Risk assessment for side-effects of neonicotinoids against bumblebees with and without impairing foraging behavior. Ecotoxicology 19, 207-215. doi: 10.1007/s10646-009-0406-2

Mommaerts, V., and Smagghe, G. (2011). "Side-effects of pesticides on the pollinator Bombus: an overview," in Pesticides in the Modern World-Pests Control and Pesticides Exposure and Toxicity Assessment, ed M. Stoytcheva (Rijeka: InTech), 508-552.

Morales, C. L., Arbetman, M. P., Cameron, S. A., and Aizen, M. A. (2013). Rapid ecological replacement of a native bumble bee by invasive species. Front. Ecol. Environ. 11:529-534. doi: 10.1890/120321

Morandin, L. A., and Winston, M. L. (2003). Effects of novel pesticides on bumble bee (Hymenoptera: Apidae) colony health and foraging ability. Environ. Entomol. 32, 555-563. doi: 10.1603/0046-225X-32.3.555

Müller, C. B., and Schmid-Hempel, P. (1992). Correlates of reproductive success among field colonies of Bombus lucorum: the importance of growth and parasites. Ecol. Entomol. 17, 343-353. doi: 10.1111/j.1365-2311.1992.tb01068.x

Piiroinen, S., Botías, C., Nicholls, E., and Goulson, D. (2016). No effect of low-level chronic neonicotinoid exposure on bumblebee learning and fecundity. PeerJ 4:e1808. doi: 10.7717/peerj.1808

Pistorius, J., Bischoff, G., Heimbach, U., and Stähler, M. (2009). Bee poisoning incidents in Germany in spring 2008 caused by abrasion of active substance from treated seeds during sowing of maize. Julius Kühn Archiv. 423, 118-126. Available online at: http://fera.co.uk/news/resources/documents/chem-JKI_ Archiv_423.pdf

Plowright, R. C., Pendrel, B. A., and McLaren, I. A. (1978). The impact of aerial fenitrothion spraying upon the population biology of bumble bees (Bombus Latr.: Hym.) in south-western New Brunswick. Can. Entomol. 110, 1145-1156.

Plowright, R. C., and Rodd, F. H. (1980). The effect of aerial insecticide spraying on hymenopterous pollinators in New Brunswick. Can. Entomol. 112, 259-269. doi: 10.4039/Ent112259-3

Pomeroy, N. (1979). Brood bionomics of Bombus ruderatus in $\mathrm{New}$ Zealand (Hymenoptera: Apidae). Can. Entomol. 111, 865-874. doi: 10.4039/Ent111865-8

Potts, S., Biesmeijer, K., Bommarco, R., Breeze, T., Carvalheiro, L., and Franzen, M. (2015). Status and Trends of European pollinators. Key Findings of the STEP project. Sofia: Pensoft Publishers. Available online at: http://step-project.net/img/uplf/STEP\%20brochure\%20online-1.pdf

Přidal, A., and Hofbauer, J. (1996). Laboratory rearing and nutrition of young queens of bumblebee (Bombus terrestris L.) from emergence to diapause. Sci. Stud. Res. Inst. Fodder Plants Troubsko 14, 125-131.

Rundlöf, M., Andersson, G. K., Bommarco, R., Fries, I., Hederström, V., Herbertsson, L., et al. (2015). Seed coating with a neonicotinoid insecticide negatively affects wild bees. Nature 521, 77-80. doi: 10.1038/nature 14420

Russo, L., Park, M., Gibbs, J., and Danforth, B. (2015). The challenge of accurately documenting bee species richness in agroecosystems: bee diversity in eastern apple orchards. Ecol. Evol. 5, 3531-3540. doi: 10.1002/ece3.158

Sammataro, D., and Avitabile, A. (1998). The Beekeeper's Handbook, 3rd Edn. Ithaca, NY: Cornell University Press.

Sanchez-Bayo, F., and Goka, K. (2014). Pesticide residues and bees-a risk assessment. PLoS ONE 9:e94482. doi: 10.1371/journal.pone.0094482

Sánchez-Bayo, F., and Tennekes, H. A. (2015). Environmental Risk Assessment of Agrochemicals - A Critical Appraisal of Current Approaches, Toxicity and Hazard of Agrochemicals, ed M. Larramendy (InTech). Available online at: http://www.intechopen.com/books/toxicity-and-hazard-of-agrochemicals/ environmental-risk-assessment- of-agrochemicals-a-critical-appraisal-ofcurrent-approaches

Scheper, J., Reemer, M., van Kats, R., Ozinga, W. A., van der Linden, G. T., Schaminée, J. H., et al. (2014). Museum specimens reveal loss of pollen host 
plants as key factor driving wild bee decline in The Netherlands. Proc. Natl. Acad. Sci. U.S.A. 111, 17552-17557. doi: 10.1073/pnas.1412973111

Scholer, J., and Krischik, V. (2014). Chronic exposure of imidacloprid and clothianidin reduce queen survival, foraging, and nectar storing in colonies of Bombus impatiens. PLoS ONE 9:e91573. doi: 10.1371/journal.pone. 0091573

Stanley, D. A., Russell, A. L., Morrison, S. J., Rogers, C., and Raine, N. E. (2016). Investigating the impacts of field-realistic exposure to a neonicotinoid pesticide on bumblebee foraging, homing ability and colony growth. J. Appl. Ecol. 53, 1440-1440. doi: 10.1111/1365-2664.12689

Sterk, G., Peters, B., Gao, Z., and Zumkier, U. (2016). Large-scale monitoring of effects of clothianidin-dressed OSR seeds on pollinating insects in Northern Germany: effects on large earth bumble bees (Bombus terrestris). Ecotoxicology 25, 1-13. doi: 10.1007/s10646-016-1723-x

Stoner, K. A., and Eitzer, B. D. (2013). Using a hazard quotient to evaluate pesticide residues detected in pollen trapped from honey bees (Apis mellifera) in Connecticut. PLOS ONE 8:e77550. doi: 10.1371/journal.pone. 0077550

Straub, L., Williams, G. R., Pettis, J., Fries, I., and Neumann, P. (2015). Superorganism resilience: eusociality and susceptibility of ecosystem service providing insects to stressors. Curr. Opin. Insect Sci. 12, 109-112. doi: $10.1016 /$ j.cois.2015.10.010

Stubbs, C. S., Jacobson, H. A., Osgood, E. A., and Drummond, F. A. (1992). Alternative Forage Plants for Native (Wild) Bees Associated with Lowbush Blueberry, Vaccinium spp., in Maine (No. 148). Orono, ME: University of Maine.

Szabo, N. D., Colla, S. R., Wagner, D. L., Gall, L. F., and Kerr, J. T. (2012). Do pathogen spillover, pesticide use, or habitat loss explain recent North American bumblebee declines? Conserv. Lett. 5, 232-239. doi: 10.1111/j.1755-263X.2012. 00234.x

Tasei, J. N., Lerin, J., and Ripault, G. (2000). Sub-lethal effects of imidacloprid on bumblebees, Bombus terrestris (Hymenoptera: Apidae), during a laboratory feeding test. Pest Manage. Sci. 56, 784-788. doi: 10.1002/1526-4998(200009)56:9andlt;784::AID-PS208andgt;3.0.CO;2-T

Thompson, H. M. (2001). Assessing the exposure and toxicity of pesticides to bumblebees (Bombus sp.). Apidologie 32, 305-321. doi: 10.1051/apido:2001131

Thompson, H. M., and Hunt, L. V. (1999). Extrapolating from honeybees to bumblebees in pesticide risk assessment. Ecotoxicology 8, 147-166. doi: 10.1023/A:1026444029579
USEPA (United States Environmental Protection Agency) (2016). Preliminary Pollinator Assessment to Support the Registration Review of Imidacloprid. EPA-HQ-OPP-2008-0844-0140. Available online at: https://www.regulations.gov/document?D=EPA-HQ-OPP-2008-0844-0140

Vanengelsdorp, D., and Meixner, M. D. (2010). A historical review of managed honey bee populations in Europe and the United States and the factors that may affect them. J. Invertebr. Pathol. 103, S80-S95. doi: 10.1016/j.jip.2009.06.011

Votavová, A., Tomčala, A., Kofroňová, E., Kudzejová, M., Šobotník, J., Jiroš, P., et al. (2015). Seasonal dynamics in the chemistry and structure of the fat bodies of bumblebee queens. PLOS ONE 10:e0142261. doi: 10.1371 /journal.pone.0142261

Whitehorn, P. R., O'Connor, S., Wackers, F. L., and Goulson, D. (2012). Neonicotinoid pesticide reduces bumble bee colony growth and queen production. Science 336, 351-352. doi: 10.1126/science.1215025

Williams, P., Colla, S., and Xie, Z. (2009). Bumblebee vulnerability: common correlates of winners and losers across three continents. Conserv. Biol. 23, 931-940. doi: 10.1111/j.1523-1739.2009.01176.x

Williams, P. H., and Osborne, J. L. (2009). Bumblebee vulnerability and conservation world-wide. Apidologie 40, 367-387. doi: 10.1051/apido/2009025

Wu-Smart, J., and Spivak, M. (2016). Sub-lethal effects of dietary neonicotinoid insecticide exposure on honey bee queen fecundity and colony development. Sci. Rep. 6:32108. doi: 10.1038/srep32108

Xerces Society (2014). The Wilsonville Bee Kill. Available online at: http://www.xerces.org/the-wilsonville-bee-kill/

Xie, Z., Williams, P. H., and Tang, Y. (2008). The effect of grazing on bumblebees in the high rangelands of the eastern Tibetan Plateau of Sichuan. J. Insect Conserv. 12, 695-703. doi: 10.1007/s10841-008-9180-3

Conflict of Interest Statement: The author declares that the research was conducted in the absence of any commercial or financial relationships that could be construed as a potential conflict of interest.

Copyright (๑) 2016 Stoner. This is an open-access article distributed under the terms of the Creative Commons Attribution License (CC BY). The use, distribution or reproduction in other forums is permitted, provided the original author(s) or licensor are credited and that the original publication in this journal is cited, in accordance with accepted academic practice. No use, distribution or reproduction is permitted which does not comply with these terms. 